\title{
Gorgonian disease outbreak in the Gulf of Naples: pathology reveals cyanobacterial infection linked to elevated sea temperatures
}

\author{
F. Carella ${ }^{1, *}$, S. Aceto $^{1}$, M. Saggiomo ${ }^{2}$, O. Mangoni ${ }^{1}$, G. De Vico ${ }^{1}$ \\ ${ }^{1}$ Department of Biology, University of Naples Federico II, 80134 Naples, Italy \\ ${ }^{2}$ Stazione Zoologica Anton Dohrn, 80121 Naples, Italy
}

\begin{abstract}
In recent years, mass mortality events of benthic invertebrates in the Mediterranean Sea have been documented to coincide with the increased seawater temperatures associated with global climate change. Following a disease outbreak in gorgonians during the summer seasons of 2008 and 2009 in the Gulf of Naples (Tyrrhenian Sea), we conducted gross and microscopic analyses of healthy and diseased specimens of Eunicella cavolinii and E. singularis using both light and electron microscopy (SEM). Macroscopically, diseased colonies exhibited evident tissue thinning, and dead colonies showed a complete loss of polyps and coenenchyme, exposing their skeletons to settlement by fouling organisms. Histopathology revealed chronic inflammatory lesions at the polyp and axial level, characterized by amoebocyte infiltration of tissue accompanied by new apposition of melanin/gorgonin sheets. We interpreted this response as a defense against different kinds of pathogens - identified as mainly a heterogeneous consortium of filamentous cyanobacteria - and which gradually led to enlargement and hardening of the coral axis, which resembled a wood-like structure at the final stage of the disease. These processes elicited the formation of multiple inflammatory nodules and capsules, some of which were macroscopically visible. A parallel 16S rRNA and ITS analysis of the diseased tissue identified Synechococcus, Arthrospira and other uncultured cyanobacteria grouped within the Oscillatoriales. These results suggest that a cyanobacterial consortium is involved in the pathogenesis of the inflammatory disease leading to the mortality of Gorgoniaceae in the area. Finally, there were anomalously high temperatures (up to $25^{\circ} \mathrm{C}$ ) between 10 and $20 \mathrm{~m}$ depth during the sampling period, particularly in June 2009 . This supports the hypothesis that the coral skeleton may serve as a reservoir for the pathogens in cooler seasons, with warmer conditions leading to pathogen reactivation and recurring mortality events.
\end{abstract}

KEY WORDS: Eunicella cavalinii - Eunicella singularis · Coral inflammation · Melanin · PCR · Banco di Santa Croce $\cdot$ Tyrrhenian Sea $\cdot$ Ocean warming $\cdot$ Climate change

Resale or republication not permitted without written consent of the publisher

\section{INTRODUCTION}

The world's coral reefs have recently experienced severe declines; for example, hard coral cover on Caribbean reefs reportedly decreased by an average of $80 \%$ in $30 \mathrm{yr}$ (Gardner et al. 2003), while Indo-Pacific reefs have suffered an estimated coral cover loss of $50 \%$ over a similar period (Bruno \&
Selig 2007). The causes of these declines are various and complex (De Vico \& Carella 2008), including water pollution, habitat destruction, overfishing, invasive species, pathogens and global climate change (Walker \& Ormand 1982, Bryant et al. 1998, Bellwood et al. 2004). Since the first coral disease was described in 1973, evidence from field studies documenting the population- and community-level 
impacts of disease on coral reef ecosystems worldwide has been accumulating (Patterson et al. 2002, Weil 2004, De Vico \& Carella 2008, Mouchka et al. 2010), and it is now clear that coral diseases have the potential to cause widespread mortality and significantly alter reef community structure (Porter et al. 2001, Patterson et al. 2002, De Vico \& Carella 2008, Miller et al. 2009, Mouchka et al. 2010). Up to 30 coral diseases have been identified worldwide, 5 of which are identified as infectious diseases for which the respective causative agents have been characterised (Kushmaro et al. 1996, Geiser et al. 1998, Ben-Haim \& Rosenberg 2002, Patterson et al. 2002, Ben-Haim et al. 2003, Denner et al. 2003, Thompson et al. 2006). These diseases can be responsible for acute mortality leading to a rapid loss of diversity and abundance, or may have chronic, sub-lethal effects, ultimately resulting in progressive tissue loss and partial mortality of the affected colonies (De Vico \& Carella 2008). The outcome of various disease states may result in reduced growth, decreases in reproductive effort and recruitment and increased incidences of a number of coral disease-related conditions and mortality - all of which ultimately lead to ecosystem deterioration (Woodley et al. 2008). However, beyond the identification of macroscopic signs documenting disease in situ, e.g. abnormal coloration, extent and pattern of tissue loss or skeletal anomalies, little is known about disease ethiopathogenesis. This significantly hinders disease management and the detection of direct mechanistic links between the occurrence of disease and environmental perturbation (De Vico \& Carella 2008).

In recent years, mass mortality events of benthic invertebrates from various phyla have occurred in the temperate Mediterranean Sea with catastrophic effects on the coastal marine ecosystem and coral populations (Cerrano et al. 2000, Garrabou et al. 2009, Vezzulli et al. 2013). In 1999, the recorded events affected approx. 30 benthic species over hundreds of kilometres of the NW Mediterranean Sea, including Italian, French and Spanish coasts (Cerrano et al. 2000, Perez et al. 2000). Anomalous high temperature conditions during summer 1999 were identified as the main factor triggering this mortality. In this context, gorgonian populations (Eunicella cavolinii, E. singularis and Paramuricea clavata) experienced extensive damage, although differences in the degree of these impacts were observed among various geographic areas. In the above cases, the diseases were linked to a low chlorophyll content, Vibrio sp., parasites and prolonged high sea temperatures (Cerrano et al. 2000, Vezzulli et al. 2010). In late summer 2008 and 2009, local mass mortality events of anthozoans and other invertebrates were also observed in different areas along the Campania coast (Tyrrhenian Sea) and were linked to high water temperatures (Garrabou et al. 2009, Gambi et al. 2010).

The present paper describes the findings of gross, histopathological and scanning electron microscopy analyses of the sea fans Eunicella singularis and E. cavolinii during a disease outbreak occurring in summer 2008 and 2009 in the Gulf of Naples, in the Banco di Santa Croce area (Tyrrhenian Sea). Potential pathogens associated with the observed lesions were also tentatively identified using molecular diagnostic techniques. Finally, water temperature data for June 2008 and 2009 were analysed to assess the potential role of anomalous temperature conditions in the occurrence of this event.

\section{MATERIALS AND METHODS}

\section{Sampling in the Banco di Santa Croce area}

The Banco di Santa Croce is a submerged seamount complex located approximately $300 \mathrm{~m}$ from Castellammare on the eastern side of the Gulf of Naples (Tyrrhenian Sea) $\left(40^{\circ} 40.68^{\prime} \mathrm{N}, 14^{\circ} 26.00^{\prime} \mathrm{E}\right)$. It is a marine protected area of high naturalistic interest composed of various rocky seamounts that rise from $60 \mathrm{~m}$ to approximately $11 \mathrm{~m}$, forming a circular structure (Bussotti et al. 1999) (Fig. 1). In June 2008 and 2009, samples of yellow gorgonians (Eunicella cavolinii) and white gorgonians (E. singularis) were collected from the Banco di Santa Croce at approx. $18 \mathrm{~m}$ depth with technical support from Nucleo Carabinieri Subacquei of Naples, the local police divers service. Previous visual inspections were conducted to select representative sampling sites, which were photographed with a Nikon D90 digital camera. Fragments of apical branches (2 $\mathrm{cm}$ in length) were collected from randomly chosen, apparently healthy colonies (i.e. with no visible signs of disease) and diseased colonies using shears and placed in plastic bags underwater. Each clipping was returned to the laboratory in a cool box for processing within $3 \mathrm{~h}$ of collection. The samples were preserved in $4 \%$ buffered formalin, for both light and electron microscopy. Attached epibiont organisms were removed under a dissecting microscope, and the various species present were identified.

Parallel temperature profiling from the surface to a 20 m depth was carried out weekly during June 2008 and 2009 using an Idromar IM52 CTD probe. 


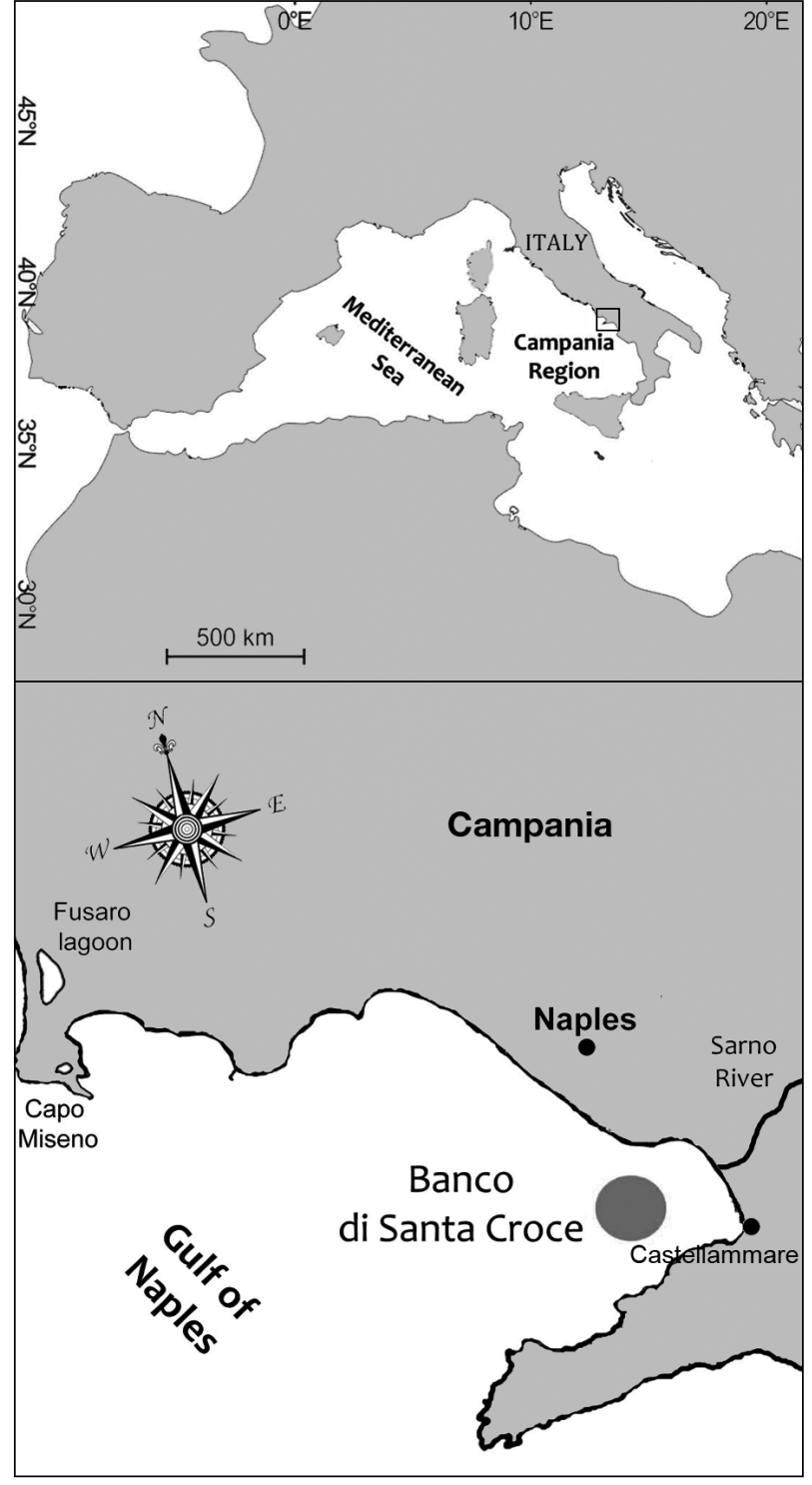

Fig. 1. Sampled study area in the Campania region of the Mediterranean Sea

\section{Light microscopy}

Gorgonian clippings were cut into both transverse and longitudinal sections, then decalcified in a 1 to $3 \%$ series of formic acid for approx. $30 \mathrm{~min}$, cleared in distilled water and stored in $70 \%$ ethanol. Subsequently, the sections were dehydrated in a graded alcohol series (50, 70, 80, $100 \%$ ), cleared in xylene and embedded in paraffin wax (Bioptica). Sections (4 to $6 \mu \mathrm{m}$ ) were cut using a rotary microtome and stained with haematoxylin and eosin (H\&E), in addition to special stains such as the Gram, Giemsa and PAS (periodic acid Schiff) stains (Mazzi 1977). All micrographs were captured using a Nikon DS-Fi1 video camera mounted on a Nikon 50i microscope and connected to a computer. An arbitrary scale was applied to define the stage of the disease (early, intermediate or final) through macro- and microscopic observation of the gorgonian axis.

\section{Scanning electron microscopy (SEM)}

Samples preserved in $4 \%$ formaldehyde were dehydrated in an ethanol series $(10,25,50,70,80,95$, $100 \%)$ and critical-point dried. This method allows the integrity of the samples and of the associated microorganisms to be maintained. The fragments were mounted on stubs and coated with platinum for SEM (JEOL JSM-6700F).

\section{DNA isolation, PCR amplification, cloning and sequencing}

Following histopathological examination of the $\mathrm{Eu}$ nicella specimens, DNA was isolated from formalinpreserved coral branches according to the protocol described by Wirgin et al. (1997), with some modifications to enhance the recovery of cyanobacterial DNA (Saha et al. 2005). Branch clippings (4 mm length) from diseased $(n=4)$ and healthy $(n=4)$ corals were incubated in $10 \mathrm{ml}$ of TE9 buffer ( $500 \mathrm{mM}$ Tris, $20 \mathrm{mM}$ EDTA, $10 \mathrm{mM} \mathrm{NaCl} ; \mathrm{pH}$ 9) at room temperature overnight with shaking. The buffer was then removed, and $10 \mathrm{ml}$ of fresh TE9 buffer was added, followed by incubation for $2 \mathrm{~h}$, after which the buffer was changed 3 times every $3 \mathrm{~h}$ during an overnight incubation. On the third day, samples were scraped from the gorgonian polyps and axis with a sterile scalpel blade, then minced and homogenised in $200 \mu \mathrm{l}$ of TE buffer (50 mM Tris, 10 mM EDTA; pH 8.0) with $50 \mu \mathrm{l}$ of lysozyme $\left(25 \mathrm{mg} \mathrm{ml}^{-1}\right)$, and the mixture was incubated for $1 \mathrm{~h}$ at $37^{\circ} \mathrm{C}$. Immediately after lysozyme treatment, $50 \mu \mathrm{l}$ of $10 \%$ sodium dodecyl sulphate (SDS) was added, and the sample was vortexed. Approximately $10 \mathrm{~min}$ later, the tubes were incubated for $1 \mathrm{~h}$ at $55^{\circ} \mathrm{C}$ with $3 \mu \mathrm{l}$ of Proteinase $\mathrm{K}\left(20 \mathrm{mg} \mathrm{ml}^{-1}\right)$. The homogenates were incubated overnight at $55^{\circ} \mathrm{C}$. One additional aliquot of both Proteinase $\mathrm{K}$ and SDS was added to the homogenates over the course of the next $24 \mathrm{~h}$. Subsequently, phenol/chloroform/isoamyl alcohol purification was performed according to Andres \& Thummel (1994). The quality of the extracted DNA was verified on a $1 \%$ agarose gel stained with ethidium bromide and quantified with a NanoDrop 2000c spectrophotometer (ThermoScientific). 
The universal cyanobacterial primers CYA106F (CGG ACG GGT GAG TAA CGC GTG A) and CYA781R - an equimolar mixture of CYA781R(a) (GAC TAC TGG GGT ATC TAA TCC CAT T) and CYA781(b) (GAC TAC AGG GGT ATC TAA TCC CTT T; Nübel et al. 1997) - were used to amplify an approx. $650 \mathrm{bp}$ region of the 16S rRNA gene, applying the thermal conditions reported in Nübel et al. (1997). Moreover, specific primers for the amplification of the ribosomal ITS from the genus Arthrospira (approx. 350 bp) were used (16S3'F: TGY GGC TGG ATC ACC TCC TT; CLIR: CAG TCA CCA ACT CTC AAT TTC TCA A) (Baurain et al. 2002). Each reaction mixture contained $0.2 \mathrm{mM}$ each primer, $0.2 \mathrm{mM}$ each dNTP, 1× PCR reaction buffer, $0.08 \%$ (w/v) bovine serum albumin, 1.25 units of Taq DNA polymerase (Sigma) and 10 to $20 \mathrm{ng}$ of template DNA, in a final volume of $50 \mu \mathrm{l}$. Amplification was performed with initial melting at $95^{\circ} \mathrm{C}$ for $5 \mathrm{~min}$, followed by 35 cycles of $94^{\circ} \mathrm{C}$ for $1 \mathrm{~min}, 60^{\circ} \mathrm{C}$ for $1 \mathrm{~min}$ and $72^{\circ} \mathrm{C}$ for $1 \mathrm{~min}$, with a final extension at $72^{\circ} \mathrm{C}$ for $10 \mathrm{~min}$.

The amplified fragments were gel-eluted and cloned using the pGEM-T Easy Vector Cloning Kit (Promega) before being sequenced using the T7 and SP6 plasmid-specific universal primers. The sequencing reactions were run in a 310 Automated Sequencer (Applied Biosystems).

The best BLAST hits for the obtained nucleotide sequences were downloaded and aligned with their corresponding sequences (16S rRNA or ITS) using ClustalW. The 2 alignment files were employed to construct neighbour-joining (NJ) trees with 1000 bootstrap replicates using the software MEGA v. 5.2 (Tamura et al. 2011). The trees were rooted using the 16S rRNA sequence of Solibacter usitatus and the ITS sequence of Oscillatoria cf. curviceps, respectively.

\section{RESULTS}

\section{Field observations, gross and microscopical signs}

Local analysis of water temperature profiles for June 2008 and 2009 showed higher values in 2009, with a maximum temperature of $26.04^{\circ} \mathrm{C}$ being observed at the water surface. The average and maximum water temperature values recorded in the 0 to 10 and 10 to 20 depth layers are reported in Table 1.

Images of the area revealed extensive death of colonies in populations of E. cavolinii and E. singularis, represented by partial to total denudation of the axial skeleton. This loss of tissue was accompanied in some cases by colonisation by macroscopic taxa such as hydroids, bryozoans, serpulid polychaetes or algae (Fig. 2).

In transverse sections, gross observations of the polyps and axial skeletons of diseased specimens in different stages of the disease revealed a progressive thinning, flattening and shrinking of the polyps, with a parallel enlargement and hardening of the axis, which changed in colour from light yellow to brown or black, becoming darker as the disease severity increased (Figs. 3A \& 4A,C,E). In some cases, multiple prominent nodules coalescing in cauliflower-like structures, composed of few polyps and sometimes accompanied by branch fusion, were visible (Fig. 4G).

Histopathological examination of the tissues revealed chronic inflammatory lesions characterised by an infiltration of granular amoebocytes associated with layering of melanin and gorgonin at both the polyp and skeleton levels, sometimes accompanied by the formation of nodules/capsules and tissue necrosis (Figs. 4 \& 5). In healthy individuals, the gorgonian axis was composed of gorgonin fibrils in the centre and a thin layer of gorgonin at the periphery (Fig. 3B). In diseased individuals, a large increase in amoebocytes was observed, depositing yellowbrown melanin/eosinophilic gorgonin material from the periphery to the centre of the axis, leading to increased skeletal dimensions (Fig. 4B,D). In the late stage of the disease, the axial skeleton was the widest and hardest and was mainly composed of overlying sheets of melanin and gorgonin, which were macroscopically brown or black in colour and presented a wood-like structure. In this condition, the polyps were flattened and reduced in their dimensions (Fig. 4E,F). Within the reactive skeleton, Gram staining revealed the presence of filamentous Gram-negative bacteria morphologically resembling filamentous cyanobacteria were present both in the

Table 1. Mean and maximum temperatures $\left({ }^{\circ} \mathrm{C}\right)$ in the 0 to $10 \mathrm{~m}$ and 10 to $20 \mathrm{~m}$ depth layers during June 2008 and 2009 at Banco di Santa Croce

\begin{tabular}{|lcc|}
\hline & $0-10 \mathrm{~m}$ & $10-20 \mathrm{~m}$ \\
\hline $\mathbf{2 0 0 8}$ & & \\
Mean & 23.6 & 21.4 \\
Maximum & 25.8 & 23.5 \\
$\mathbf{2 0 0 9}$ & & \\
Mean & 24.7 & 22.6 \\
Maximum & 26.0 & 25.3 \\
\hline
\end{tabular}



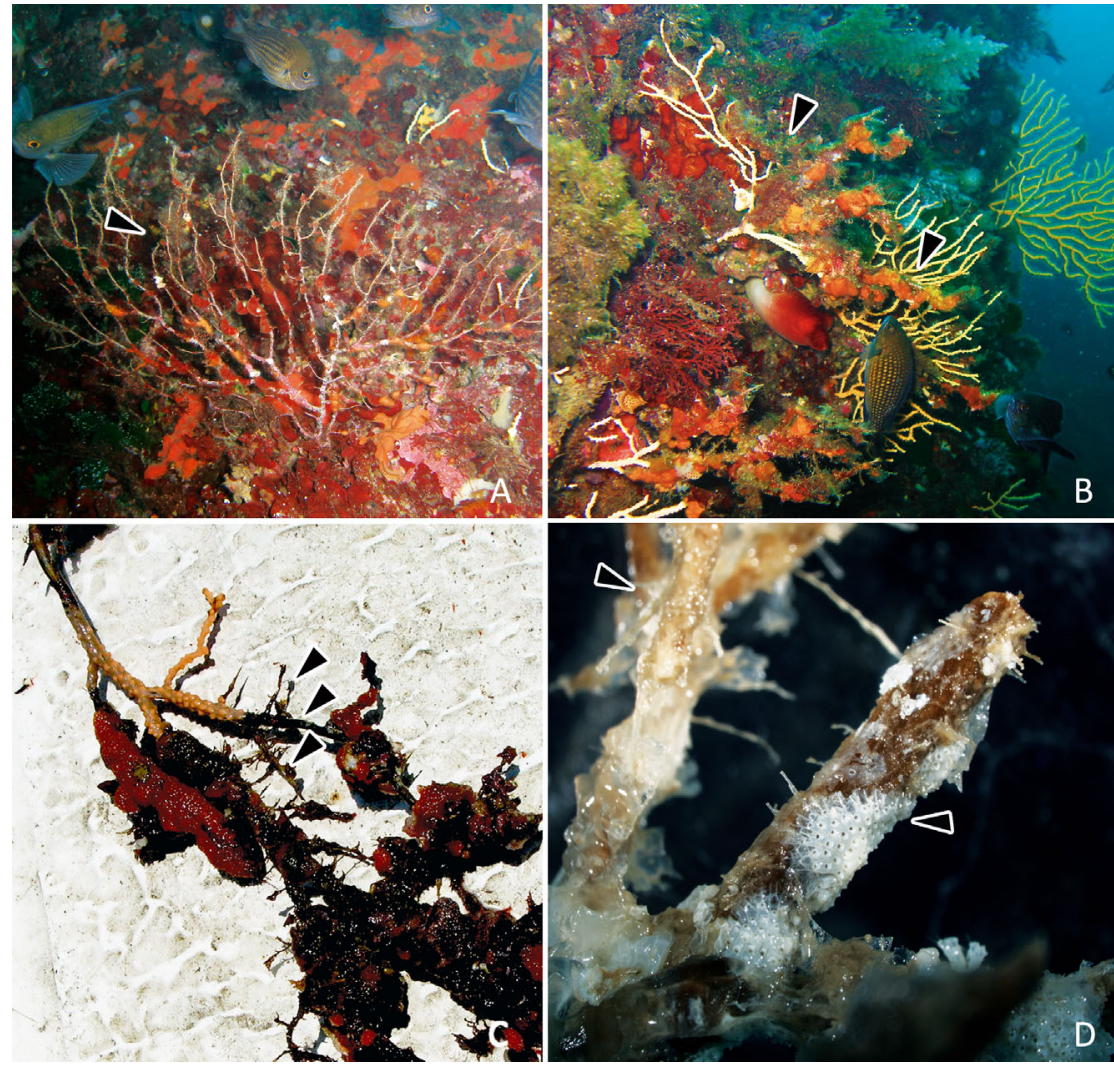

Fig. 2. Populations of Eunicella cavolinii and E. singularis at the Banco di Santa Croce in June 2008 and 2009. (A,B) Eunicella sp. with totally denuded skeletons and loss of tissue, in some cases covered by fouling organisms (arrowheads); (C) E. cavolinii with evident loss of tissue (arrowheads) and exposed skeleton; (D) higher magnification of detail of $E$. singularis and a dead branch with a wood-like structure colonised by different epibiont organisms (arrowheads)

\section{Ultrastructure}

SEM images of the skeletons of the host corals confirmed the existence of an extensive cyanobacterial consortium present at both the coenenchyme and axial levels. In some cases, this consortium was composed of several different spiral coiled filaments resembling the Arthrospira genus, which actively penetrated the coral skeleton and were present into the overlying coral tissue. Interestingly, the images showed that the elicited defensive reaction involved either layering of hard sheets of melanin and gorgonin over the entire axis, deposited by amoebocytes, or a local defence mechanism within the axial skeleton, embedding the filamentous pathogens (Fig. 6).

\section{Sequence analysis}

No PCR products were obtained from healthy specimens. From diseased animals, a total of 20 colonies were screened both for 16S rRNA and ITS sequence, and the obtained results matched coenenchyme and within the axis. In other cases, cyanobacteria were also detected into the overlying tissue of the corals, throughout the mesoglea between tissue layers (coral epidermis and gastrodermis) (Fig. 5).
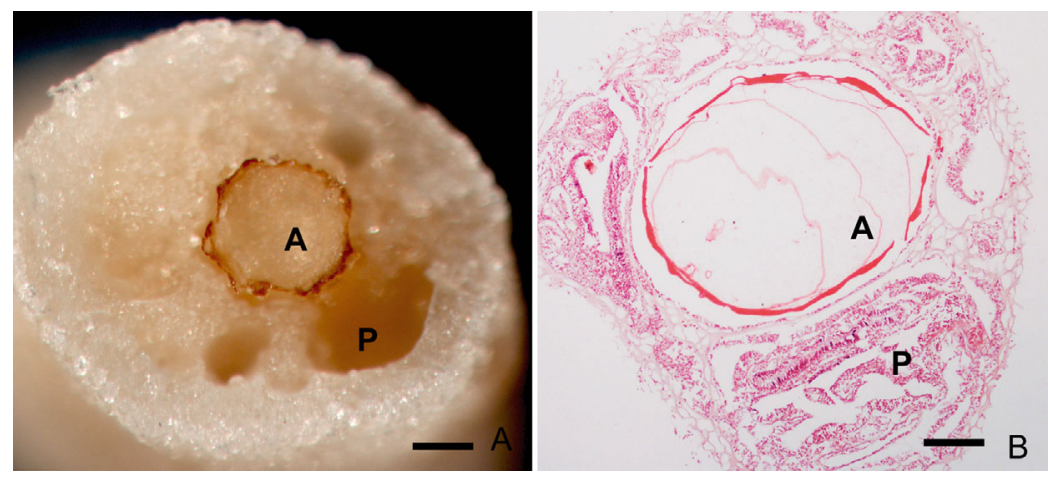

Fig. 3. (A) Gross and (B) microscopic observation of the axial skeleton in control specimens of Eunicella singularis. A: axis; P: polyp. Scale bars $=(A) 1 \mathrm{~mm}$, (B) $500 \mu \mathrm{m}$ cyanobacteria for $4(20 \%)$ and $3(15 \%)$ clones, respectively. The remaining cloned fragments showed positive matches with various strains of uncultured bacteria. The identity of the sequences from this study were very similar to cyanobacterial sequences present in GenBank, ranging from $97 \%$ (COL13 vs. Halospirulina sp.) to $100 \%$ (COL1 vs. Arthrospira indica).

Fig. 7 shows the NJ trees based on the alignment of the nucleotide sequences of the 16S rRNA and ITS sequences obtained in the present study with their best-matching BLAST hits downloaded from GenBank. The 16S rRNA tree (Fig. 7A) shows that COL2 and COL13 are grouped together with uncultured cyanobacteria sister group of Halospirulina sp. and Planktothricoides sp. (Oscillatoriales). 


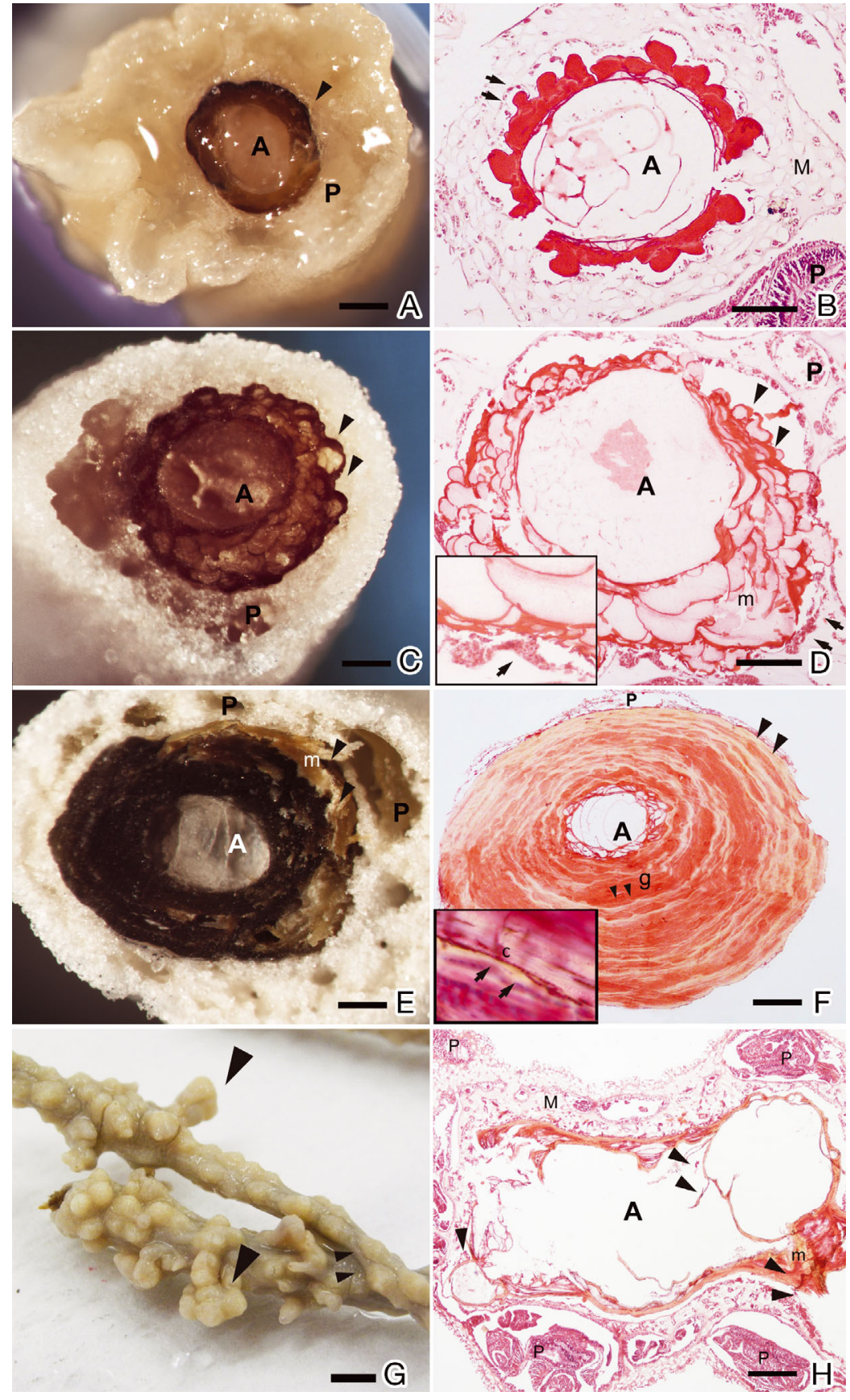

Fig. 4. Gross (left) and microscopic (right) observations of the axial skeletons of diseased specimens in different stages of the disease. (A,B) Detailed image of the axis and black border (arrowhead in A) of melanin in an early stage of the disease; in (B) amoebocytes depositing eosinophilic/yellowish material (arrows) are also visible. (C,D) Deposition of gorgonin (arrowheads) by amoebocytes (arrows in D) in an intermediate stage of the disease. $(\mathrm{E}, \mathrm{F})$ Gross appearance of a denuded skeleton with a black/brownish colour and yellow sheets, in which histology revealed various layers of melanin (large arrowheads) and eosinophilic gorgonin (small arrowheads) sheets; late stage of the disease and the presence of filamentous PAS-positive cyanobacteria (arrows in inset). (G) Visible nodules (large arrowheads) and branch fusion (small arrowheads) in the coral skeleton. $(\mathrm{H})$ Inflammatory nodules composed of gorgonin and melanin (arrowheads). A: axis; P: polyp; m: melanin; g: gorgonin; C: cyanobacteria; $\mathrm{M}$ : mesoglea. Scale bar for gross observations $=1 \mathrm{~mm}$; scale bar for histology $=500 \mu \mathrm{m}$; scale bar in $\mathrm{G}=5 \mathrm{~mm}$
COL11 and COL18 belong to a different branch of uncultured cyanobacteria that includes Synechococcus sp. (Chroococcales). The topology of the tree obtained from the analysis of ITS sequences (Fig. 7B) indicates that COL1 and COL5 are grouped together with Arthrospira indica, whereas COL3 is more similar to A. platensis (Oscillatoriales).

The obtained sequences were deposited in GenBank under the following accession numbers: KJ574138 for COL11, KJ574139 for COL18, KJ574140 for COL13, KJ574141 for COL2, KJ574142 for COL3, KJ574143 for COL5, and KJ574144 for COL1.

\section{DISCUSSION}

The sea fans Eunicella cavolinii and E. singularis are gorgonians that dominate the benthic shallow-water communities found on rock faces in the Mediterranean Sea (Weinberg 1978, Gili \& Ros 1985, Bo et al. 2011). Reports of diseases among this genus are limited to Vibrio infections of $E$. verrucosa in UK waters and E. singularis and E. cavolinii in the Tyrrhenian Sea (Martin et al. 2002), or to ciliate infections in the same geographic area (Cerrano et al. 2000). Along the Campania coast (Tyrrhenian Sea), mortality events in Mediterranean species were documented in the Gulf of Naples in 2002 and 2003, related to a large-scale heatwave (Garrabou et al. 2009), and in 2005, related to a local thermal anomaly (Cigliano \& Gambi 2007). Despite the increasing number of coral diseases being reported globally, little is known about many of these pathological conditions, including their aetiologies and ethiopathogenesis and the steps that can be taken to prevent, control, or reduce their impacts (Pollock et al. 2011). In the present study, the observed gross and microscopic features revealed a chronic inflammatory reaction towards a consortium of 


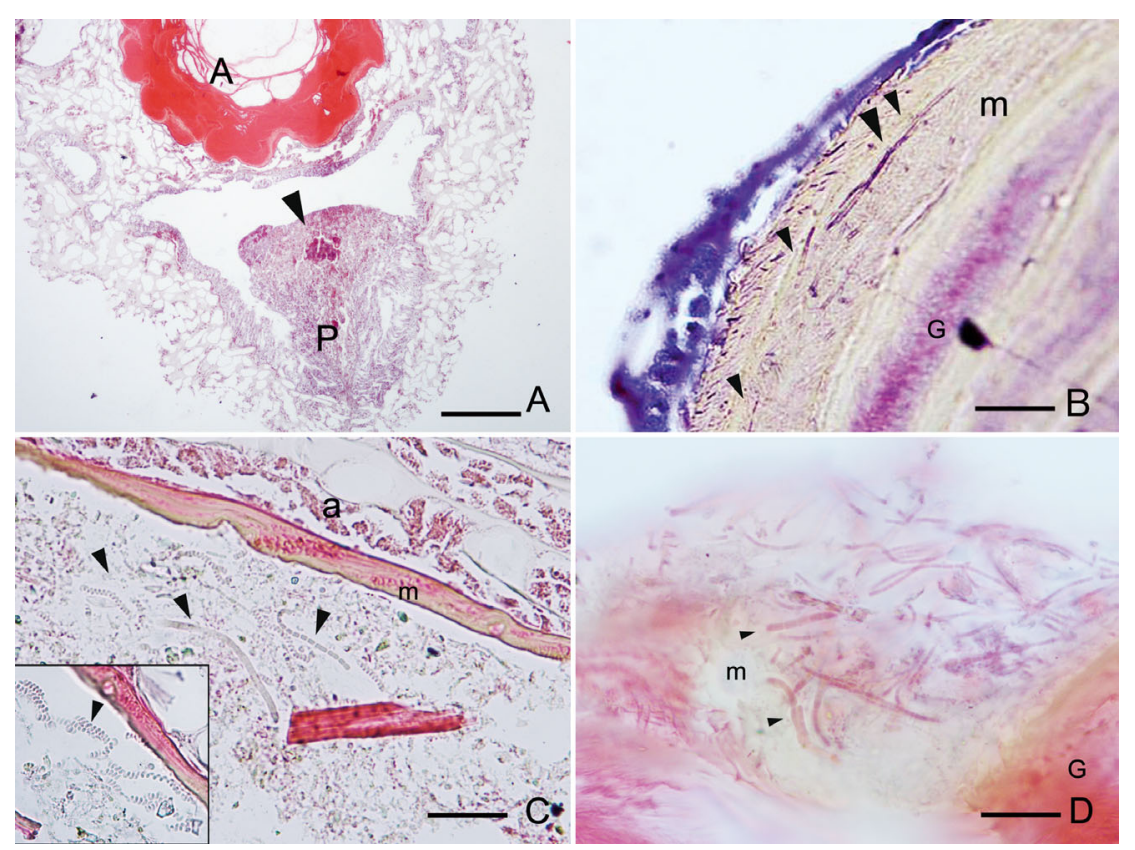

Fig. 5. Histological observations of the polyps and axes of Eunicella cavolinii and E. singularis harbouring a consortium of filamentous cyanobacteria. (A) Necrotic area at polyp level (arrowhead) of E. cavolinii (scale bar $=150 \mu \mathrm{m}$ ); (B) Gram-negative filamentous bacteria within the axis (arrowheads) in E. singularis (scale bar $=20 \mu \mathrm{m}$ ); (C) heterogeneous consortium of cyanobacteria within the axis (arrowheads) and evidence of members of the Arthrospira genus (insert) in E. cavolinii (scale bar = $50 \mu \mathrm{m}$ ); (D) filamentous cyanobacteria (small arrowheads) associated with evident formation of an inflammatory capsule composed of yellow melanin and eosinophilic gorgonin E. singularis (scale bar $=10 \mu \mathrm{m}$ ). A: axis; P: polyp; m: melanin; G: gorgonin; a: amoebocytes

cyanobacteria involved in a disease outbreak in the corals E. cavolinii and E. singularis during the summer seasons of 2008 and 2009 in the Gulf of Naples. In this context, histopathology has been advocated as a well-established diagnostic technique for detecting the pathogens present in coral lesions, which are useful for suggesting possible pathogenetic mechanisms for coral diseases (Work et al. 2008). Thus, histopathology provides clues about organisms that could be associated with disease. For example, a potential etiologic agent (bacterium, fungus, parasite or virus) may be visibly associated with cellular and tissue damage when viewed under either light or electron microscopy. A strong assumption of an association can be inferred in cases where the presumptive aetiology is consistently associated with lesions and is absent, or greatly reduced, in healthy tissue (Work et al. 2008). In the present study, in diseased animals, cyanobacterial infections were observed within the coral skeleton and penetrating into coral tissue, linked to tissue injury.

Like other invertebrates, both scleractinians (Hexacorallia) and gorgonians (Octocorallia) possess in- nate or natural immunity, which is a nonspecific ability to react to invading microorganisms by actively producing barriers to the potential invader (De Vico \& Carella 2012). Basic host defences include mechanical or physical barriers (e.g. mucus, epidermis), secretion of chemicals (e.g. acid) or production of bioactive compounds (e.g. antimicrobial peptides), in addition to phagocytic cells that can engulf and destroy microorganisms on contact (Robbins et al. 1999). The cellular response consists of fixed or circulating amoeboid phagocytes that ingest microscopic organisms and kill them by exposure to proteolytic enzymes and free oxygen radicals (Mullen et al. 2004). Moreover, gorgonian cells can be induced to produce gorgonin to wall off infiltrating fungi and algae, leading to the formation of defensive nodules or capsules (Morse et al. 1977). In addition to the cell-mediated system, corals produce melanin as the end-point of the prophenoloxidase cascade, which is usually activated during pathogen invasion. Melanin deposition within the context of skeletal layering represents an integral part of the immune-inflammatory response in this taxon and is involved in pathogen encapsulation, which constitutes a potent physiochemical barrier to microbial spreading within host tissues (Mydlarz et al. 2010, Mydlarz \& Palmer 2011, Pollock et al. 2011). In this work, the defensive reaction against the observed pathogens consisted of thick layers of melanin and gorgonin released by granular amoebocytic cells. Interestingly, this response gradually led to an enlargement/hardening of the coral skeleton, which typically resembled a wood-like structure in the final stage of the disease. Other studies have shown that gorgonians may react to invasion by separating the pathogens from host tissue with a proteinaceous capsule, along with melanin deposition (Goldberg et al. 1984). Gorgonia ventalina responds to infiltrating filamentous algae by forming grossly visible nodules that are mostly composed of gorgonin and melanin (Morse et al. 1977), which has also been reported by Petes et al. (2003) during mycotic infec- 


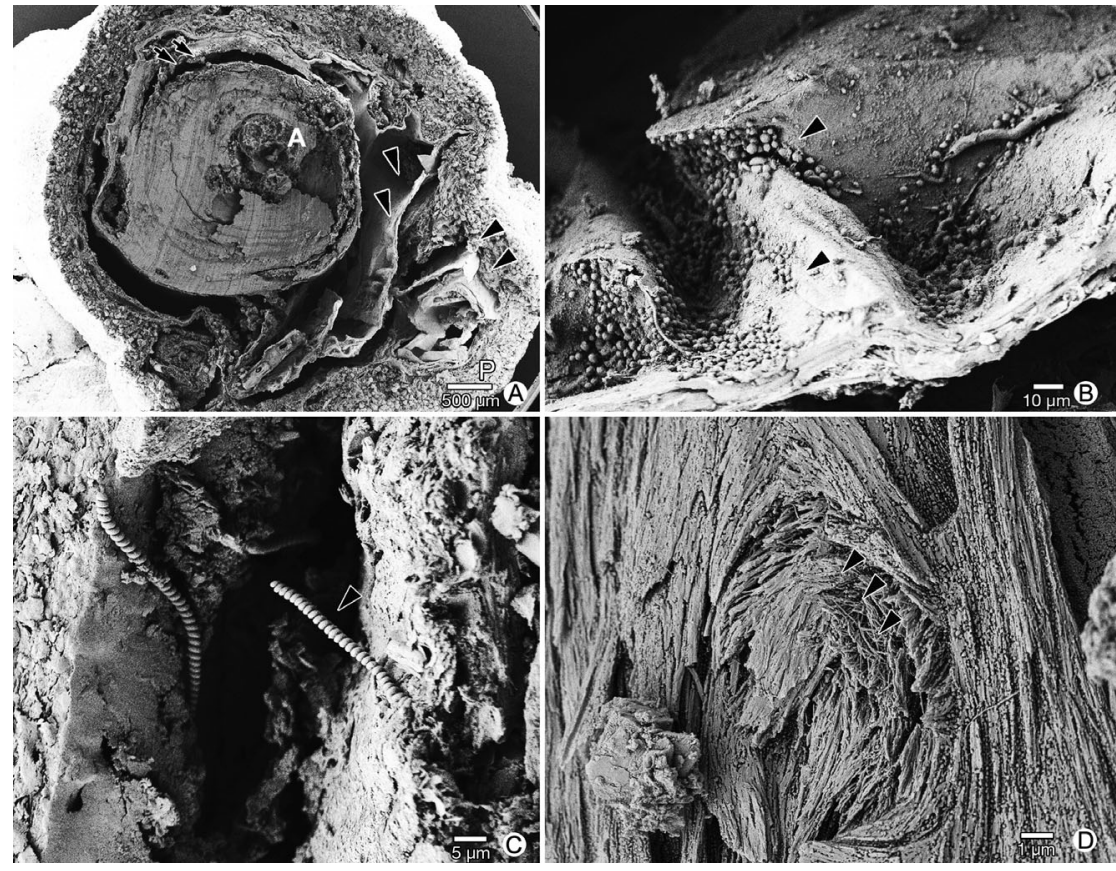

Fig. 6. Scanning electron microscopy (SEM) images of diseased Eunicella cavolinii and E. singularis at the Banco di Santa Croce. (A) Transverse section of a gorgonian axis showing evidence of the presence of sheets of melanin (large arrowheads) within the coenenchyme and axial skeleton, reaching the polyps, and the presence of filamentous bacteria within the axis (small arrows); (B) detail of (A) showing amoebocyte deposition of melanin (arrowheads); (C) Cyanobacteria (Arthrospira; arrowhead) migrating within and between the septae of the coenenchyme and coral polyps; (D) inflammatory capsule circumscribing the pathogen (arrowheads). A: axis; P: polyp

tions and in Pseudoplexaura sp., where defensive encapsulation (improperly referred to as 'tumours') was observed in specimens in the Florida Keys infected by the green algae Entocladia endozoica (Goldberg et al. 1984).

Infectious diseases are recognised as significant contributors to the dramatic loss of corals observed worldwide. Multiple species of cyanobacteria have been identified as being responsible for human and coral disease (Carmichael et al. 2001, Miller et al. 2011). In particular, cyanobacteria are involved in the so-called BBD (black Band Disease), a well-defined disease mostly observed in massive frameworkbuilding corals that is macroscopically defined by a dark or red band composed of a specific, complex microbial assemblage and associated with a sulphide-rich microbial mat and heterotrophic bacteria. In gorgonian soft corals, the cyanobacterium Phormidium corallyticum has been observed in infections of Pseudopterogorgia acerosa in the northern Florida Keys (Feingold 1988), causing the mortality of several animal colonies. Moreover, Scytonema spp. cyanobacteria have been associated with dis- ease in the Caribbean gorgonian Briareum asbestinum during a bleaching event associated with high sea surface temperatures (Harvell et al. 2001). In the present study, a parallel 16S rRNA and ITS analysis identified Synechococcus, Arthrospira and other uncultured cyanobacteria grouped within the Oscillatoriales, which are often identified in coral diseases.

Increased temperatures and light intensities can enhance the progression and spread of cyanobacterial infection (e.g. Porter et al. 2001, Boyett et al. 2007, Sato et al. 2011). Under this scenario, diseases involving microbial agents are often considered opportunistic infections. Temperature is a key environmental factor that affects organisms at all levels of organisation by controlling their physiological and ecological processes (Calosi et al. 2008). As a result of physiological stress due to increased seawater temperatures, host resistance is reduced, and unchecked growth of bacteria that are normally benign and non-pathogenic occurs (Glas et al. 2012). The association between increased global temperatures and the emergence of coral diseases has been correlated with elevated temperatures in the water column worldwide, consistent with the hypothesis that climate change facilitates the growth of opportunistic pathogens, leading to disease. Among the most strongly affected organisms are sessile invertebrate species, which play important roles in the structure and function of their habitats (Helmuth et al. 2002, Somero 2005, Oliver \& Palumbi 2011). In this context, disease outbreaks have impacted an increasing range of marine organisms in different geographic regions worldwide (Harvell et al. 1999, 2007, Carella et al. 2011, 2013a,b,c). In the Mediterranean Sea, mortality has been recorded in the context of regional warming (Romano et al. 2000, Crisci et al. 2011), and thermally dependent pathogens are considered to share the responsibility for mass mortalities and coral bleaching (e.g. Bally \& Garrabou 2007), which has also been reported in both deep and coastal waters in the Campania region (Bethoux et al. 1990, Cigliano \& 

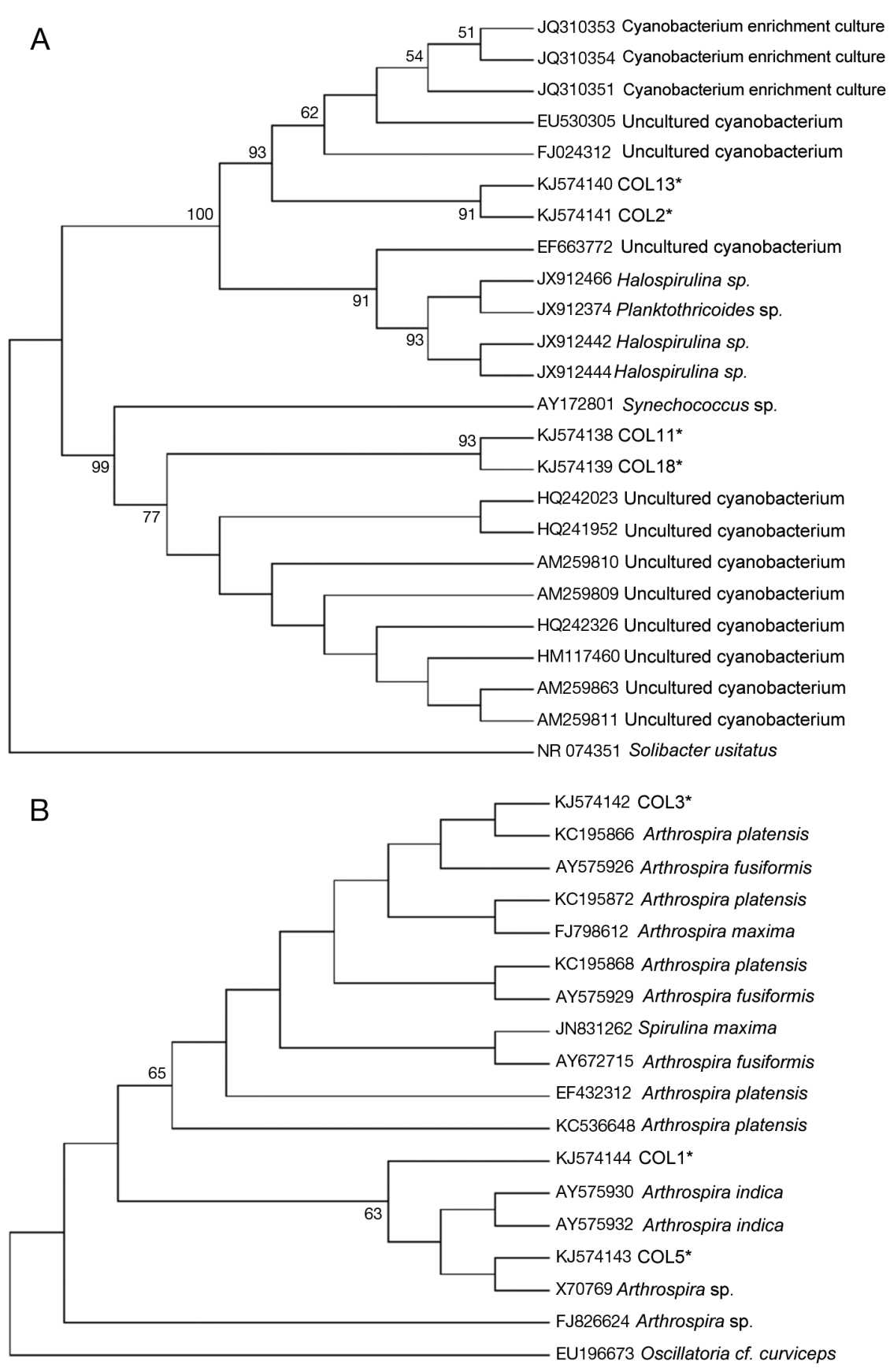

Fig. 7. Neighbor-joining trees obtained from the nucleotide alignment of (A) $16 \mathrm{~S}$ rRNA and (B) ITS in both species studied of diseased gorgonians. The alphanumerical code indicates the GenBank accession number; the numbers at the nodes represent the bootstrap percentages (values lower than $50 \%$ are not indicated). * Sequences obtained in the present work

Gambi 2007, Diffenbaugh et al. 2007, Vargas-Yanez et al. 2008). Previous studies have indicated that gorgonians have been affected by mass mortality events in the northwestern Mediterranean basin, encompassing Italy, Spain and France (Cerrano et al. 2000, Perez et al. 2000, Coma et al. 2006, 2009, FerrierPagès et al. 2009, Garrabou et al. 2009), providing clear evidence of the absence of a single mass mortality threshold for species and populations, which may be modulated by both physical and biological factors. Moreover, many coral diseases display seasonal variations in prevalence, with higher prevalences being observed in warm summer months (Rosenberg \& Ben-Haim 2002). The hypothesis that has been put forth concerning summer mortality episodes, which has also been applied in other cases of disease (Kuta \& Richardson 1997, Sato et al. 2009, Miller et al. 2011), is that the coral skeleton may serve as a reservoir of pathogens that persist in low numbers in cooler seasons. When more favourable 
warmer conditions return, cyanobacterial numbers may again increase and reinfect the coral. In the present study, the temperature values recorded during the month of June in the 2 different years were relatively high, especially in 2009 , with an average temperature of $22.6^{\circ} \mathrm{C}$ observed in the 10 to $20 \mathrm{~m}$ layer (i.e. at the depth of the E. singularis and E. cavolinii populations) confirming the existence of warming in the summer in the Gulf of Naples (Gambi et al. 2010).

Taken together, the above environmental, molecular and histopathological findings strongly suggest that the cyanobacteria detected within damaged coral tissues in the present study could be part of a pathogenic community affecting E. singularis and E. cavolinii from the Banco di Santa Croce in the warming Tyrrhenian Sea. To the best of our knowledge, this represents the first report suggesting an association between a cyanobacterial consortium and a disease outbreak involving octocorals in the Mediterranean basin, further supporting the current concern about the ecological and biomedical consequences of global climate change and the associated redistribution of pathogens at the latitudes of this study.

The correlation between the long-term data on environmental conditions, such as temperature and turbidity, in relation to the distribution of colony densities and damage among E. singularis and E. cavolinii shows that these species could be potential indicators of environmental variations (Painting \& Forster 2013). Hence, analyses of the spatial and temporal evolution of these species could be applied within the framework of Marine Strategy Framework Directive as an indicator of anthropogenic impacts as well as the influence of climate change.

Acknowledgements. The authors thank the Nucleo Carabinieri Subacquei di Napoli for field and diving support, and Franco Iamunno (Stazione Zoologica di Napoli Anton Dohrn) and Dr. Grazia Villari (University Federico II of Naples) for their technical support in scanning electron microscopy and light microscopy, respectively.

\section{LITERATURE CITED}

Andres AJ, Thummel CS (1994) Methods in quantitative analysis of transcription in larvae and prepupae. Methods Cell Biol 44:565-573

Aronson RB, Precht WF (2001) White-band disease and the changing face of Caribbean coral reefs. Hydrobiologia 460:25-38

Bally M, Garrabou J (2007) Thermo dependent bacterial pathogens and mass mortalities in temperate benthic communities: a new case of emerging disease linked to climate change. Glob Change Biol 13:2078-2088

Baurain D, Renquin L, Grubisic S, Scheldeman P, Belay A, Wilmotte A (2002) Remarkable conservation of internally transcribed spacer sequences of Arthrospira ('Spirulina') (Cyanophyceae, Cyanobacteria) strains from four continents and of recent and 30-year-old dried samples from Africa. J Phycol 38:384-393

Bellwood DR, Hughes TP, Folke C, Nystrom M (2004) Confronting the coral reef crisis. Nature 429:827-833

$>$ Ben-Haim Y, Rosenberg E (2002) A novel Vibrio sp. pathogen of the coral Pocillopora damicornis. Mar Biol 141: $47-55$

Ben-Haim Y, Zicherman-Keren M, Rosenberg E (2003) Temperature-regulated bleaching and lysis of the coral Pocillopora damicornis by the novel pathogen Vibrio coralliilyticus. Appl Environ Microbiol 69:4236-4242

Bethoux JP, Gentili B, Raunet J, Tailliez D (1990) Warming trend in the Western Mediterranean deep water. Nature 347:660-662

Bo M, Bertolino M, Castellano M, Covazzi Hariague A et al. (2011) Characteristics of the mesophotic megabenthic assemblages of the Vercelli Seamount (North Tyrrhenian Sea). PLoS ONE 6:e16357

Boyett HV, Bourne DG, Willis BL (2007) Elevated temperature and light enhance progression and spread of black band disease on staghorn corals of the Great Barrier Reef. Mar Biol 151:1711-1720

Bruno JF, Selig ER (2007) Regional decline of coral cover in the Indo-Pacific: timing, extent, and subregional comparisons. PLoS ONE 2:e711

Bryant D, Burke L, McManus J, Spalding M (1998) Reefs at risk: a map-based indicator of threats to the world's coral reefs. World Resources Institute, Washington, DC

Bussotti S, Buia MC, Di Capua I, Gambi MC and others (1999) Preliminary biocenotic characterization of the protected area 'Banco di Santa Croce' (Gulf of Naples, Italy). Biol Mar Mediterr 6:133-135

> Calosi P, Bilton DT, Spicer JI (2008) Thermal tolerance, acclamatory capacity and vulnerability to global climate change. Biol Lett 4:99-102

Carella F, Aceto S, Marrone R, Maiolino P and De Vico G (2011) Marteilia refringens infection in cultured and natural beds of mussels (Mytilus galloprovincialis) along the Campanian coast (South of Italy): first observation. Bull Eur Assoc Fish Pathol 30:189-196

> Carella F, Carrasco N, Andree KB, Lacuesta B, Furones D, De Vico G (2013a) Nocardiosis in Mediterranean bivalves: first detection of Nocardia crassotreae in a new host Mytilus galloprovincialis and in Ostrea edulis from the Gulf of Naples (Italy). J Invertebr Pathol 114:324-328

> Carella F, Culurgioni J, Aceto S, Fichi G and others (2013b) Postmonorchis sp. inq. (Digenea: Monorchiidae) metacercaria infecting natural beds of wedge clam Donax trunculus in Italy. Dis Aquat Org 106:163-172

Carella F, Aceto S, Fiengo M, Salemme M, Aniello F, Lo Muzio L, De Vico G (2013c) Correlation between the expression level of the $m d m$ homolog gene and inflammatory lesions in different populations of the model organism Mytilus galloprovincialis from polluted areas of the Gulf of Naples (southern Italy). Eur J Inflamm 11: 1721-1727

- Carmichael WW, Azevedo SMFO, An JS, Molica RJR and others (2001) Human fatalities from cyanobacteria: chemical and biological evidence for cyanotoxins. Environ Health Perspect 109:663-668 
Cerrano C, Bavestrello G, Bianchi CN, Cattaneo-vietti R and others (2000) A catastrophic mass-mortality episode of gorgonians and other organisms in the Ligurian Sea (northwestern Mediterranean), summer 1999. Ecol Lett 3:284-293

Cigliano M, Gambi MC (2007) The long hot summer: a further mortality event of gorgonians along the Phlaegrean islands (Tyrrhenian Sea). Biol Mar Mediterr 14:292-293

Coma R, Linares C, Ribes M, Diaz D, Garrabou J, Ballesteros E (2006) Consequences of a mass mortality in populations of Eunicella singularis (Cnidaria: Octocorallia) in Menorca (NW Mediterranean). Mar Ecol Prog Ser 327: $51-60$

> Coma R, Ribes M, Serrano E, Jiménez Salat J, Pascual J (2009) Global warming enhanced stratification and mass mortality events in the Mediterranean. Proc Natl Acad Sci USA 106:6176-6181

> Crisci C, Bensoussan N, Romano JC, Garrabou J (2011) Temperature anomalies and mortality events in marine communities: insights on factors behind differential mortality impacts in the NW Mediterranean. PLoS ONE 6: e23814

> De Vico G, Carella F (2008) The relevance of pathology in conservation biology of aquatic animals. Riv Biol 101: 181-186

> De Vico G, Carella F (2012) Morphological features of the inflammatory response in molluscs. Res Vet Sci 93: 1109-1115

> Denner EB, Smith GW, Busse HJ, Schumann P and others (2003) Aurantimonas coralicida gen. nov. sp. nov., the causative agent of white plague II on Caribbean scleractinian corals. Int J Syst Evol Microbiol 53:1115-1122

> Diffenbaugh NS, Pal JS, Giorgi F, Gao XJ (2007) Heat stress intensification in the Mediterranean climate change hotspot. Geophys Res Lett 34:L11706, doi:10.1029/ 2007GL030000

Feingold JS (1988) Biological studies of a cyanobacterial infection on the Caribbean sea plume Pseudopterogorgia acerosa (Coelenterata: Octocorallia). Proc 6th Int Coral Reef Symp, Townsville 3:157-162

> Ferrier-Pagès C, Tambutté E, Zamoum T, Segonds N and others (2009) Physiological response of the symbiotic gorgonian Eunicella singularis to a longterm temperature increase. J Exp Biol 212:3007-3015

Gambi MC, Barbieri F, Signorelli S, Saggiomo V (2010) Mortality events along the Campania coast (Tyrrhenian Sea) in summers 2008 and 2009 and relation to thermal conditions. Biol Mar Mediterr 17:126-127

Gardner TA, Cote IM, Gill JA, Grant A, Watkinson AR (2003) Long-term region-wide declines in Caribbean corals. Science 301:958-960

Garrabou J, Coma R, Bensoussan N, Bally M and others (2009) Mass mortality in Northwestern Mediterranean rocky benthic communities: effects of the 2003 heat wave. Glob Change Biol 15:1090-1103

> Geiser DM, Taylor JW, Ritchie KB, Smith GW (1998) Cause of sea fan death in the West Indies. Nature 394:137-138

> Gili JM, Ros J (1985) Study and cartography of the benthic communities of Medes Islands (NE Spain). Mar Ecol 6: 219-238

> Glas MS, Sato Y, Ulstrup KE, Bourne DG (2012) Biogeochemical conditions determine virulence of black band disease in corals. ISME J 6:1526-1534

Goldberg WM, Makemson JC, Colley SB (1984) Entocladia endozoica sp. nov., a pathogenic chlorophyte: structure, life history, physiology and effect on its coral host. Biol Bull 166:368-383

Harvell CD, Kim K, Burkholder JM, Colwell RR and others (1999) Emerging marine diseases-climate links and anthropogenic factors. Science 285:1505-1510

Harvell D, Kim K, Quirolo C, Weir J, Smith G (2001) Coral bleaching and disease: contributors to 1998 mass mortality in Briareum asbestinum (Octocorallia, Gorgonacea). Hydrobiologia 460:97-104

> Harvell D, Jordan-Dahlgren E, Merkel S, Rosenberg E and others (2007) Coral disease, environmental drivers, and the balance between coral and microbial associates. Oceanography 20:172-195

- Helmuth B, Harley CDG, Halpin PM, O'Donnell M, Hofmann GE, Blanchette C (2002) Climate change and latitudinal patterns of intertidal thermal stress. Science 298: 1015-1017

Kushmaro A, Loya Y, Fine M, Rosenberg E (1996) Bacterial infection and coral bleaching. Nature 380:396

Kuta K, Richardson LL (1997) Black band disease and the fate of diseased corals in the Florida Keys. Proc 8th Int Coral Reef Symp, Panama City 1:575-578

Martin Y, Bonnefort JL, Chancerelle L (2002) Gorgonians mass mortality during the 1999 late summer in French Mediterranean coastal waters: the bacterial hypothesis. Water Res 36:779-782

Mazzi V (1977) Manuale di tecniche istologiche e istochimiche. Piccin, Rome

Miller J, Muller E, Rogers C, Waara R and others (2009) Coral disease following massive bleaching in 2005 causes $60 \%$ decline in coral cover on reefs in the US Virgin Islands. Coral Reefs 28:925-937

Miller AW, Blackwelder P, Al-Sayegh H, Richardson LL (2011) Fine-structural analysis of black band diseaseinfected coral reveals boring cyanobacteria and novel bacteria. Dis Aquat Org 93:179-190

Morse DE, Morse ANC, Duncan H (1977) Algal 'tumors' in the Caribbean sea fan, Gorgonia ventalina. Proc 3rd Int Coral Reef Symp, Miami 1:623-629

> Mouchka ME, Hewson I, Harvell CD (2010) Coral-associated bacterial assemblages: current knowledge and the potential for climate-driven impacts. Integr Comp Biol 50:662-674

Mullen KM, Peters EC, Harvell CD (2004) Coral resistance to disease. In: Rosenberg E, Loya Y (eds) Coral health and disease. Springer, Heidelberg, p 377-399

Mydlarz LD, Palmer CV (2011) The presence of multiple phenoloxidases in Caribbean reef-building corals. Comp Biochem Physiol A Mol Integr Physiol 159:372-378

- Mydlarz LD, Scinti ES, Harvell CD (2010) What are the physiological and immunological responses of coral to climate warming and disease? J Exp Biol 213:934-945

Nübel U, Garcia-Pichel F, Muyzer G (1997) PCR primers to amplify 16S rRNA genes from cyanobacteria. Appl Environ Microbiol 63:3327-3332

> Oliver TA, Palumbi SR (2011) Do fluctuating temperature environments elevate coral thermal tolerance? Coral Reefs 30:429-440

Painting SJ, Forster RM (2013) Marine ecosystem connections: essential indicators of healthy, productive and biologically diverse seas. Biogeochemistry 113:1-7

Patterson KL, Porter JW, Ritchie KB, Polson SW and others (2002) The etiology of white pox, a lethal disease of the Caribbean elkhorn coral, Acropora palmata. Proc Natl Acad Sci USA 99:8725-8730 
Perez T, Garrabou J, Sartoretto S, Harmelin JG, Francour P, Vacelet J (2000) Mortalité massive d'invertébrés marins: un événement sans précédent en Méditerranée nordoccidentale. CR Acad Sci III Sci Vie 323:853-865

> Petes LE, Harvell CD, Peters EC, Webb MAH, Mullen KM (2003) Pathogens compromise reproduction and induce melanization in Caribbean sea fans. Mar Ecol Prog Ser 264:167-171

Pollock FJ, Morris PJ, Willis BL, Bourne DG (2011) The urgent need for robust coral disease diagnostics. PLoS Pathog 7:e1002183

Porter J, Dustan P, Jaap W, Patterson K and others (2001) Patterns of spread of coral disease in the Florida Keys. Hydrobiologia 460:1-24

Robbins RL, Kumar V, Collins T (eds) (1999) Pathologic basis of disease, 6th edn. Saunders, Philadelphia, PA

Romano JC, Bensoussan N, Younes WAN, Arlhac D (2000) Thermal anomaly in the waters of the Gulf of Marseilles during summer 1999. A partial explanation of the mortality of certain fixed invertebrates? CR Acad Sci III Sci Vie 323:415-427

Rosenberg E, Ben-Haim Y (2002) Microbial diseases of corals and global warming. Environ Microbiol 4:318-326

Saha SK, Uma L, Subramanian G (2005) An improved method for marine cyanobacterial DNA isolation. World J Microb Biot 21:877-881

Sato Y, Willis BL, Bourne DG (2009) Successional changes in bacterial communities during the development of black band disease on the reef coral, Montipora hispida. ISME J 4:203-214

Sato Y, Bourne DG, Willis BL (2011) Effects of temperature and light on the progression of black band disease on the reef coral, Montipora hispida. Coral Reefs 30:753-761

Somero GN (2005) Linking biogeography to physiology: evolutionary and acclimatory adjustments of thermal limits. Front Zool 2:1

Tamura K, Peterson D, Peterson N, Stecher G, Nei M, Kumar S (2011) MEGA5: molecular evolutionary genetics analysis using maximum likelihood, evolutionary distance, and maximum parsimony methods. Mol Biol Evol 28: 2731-2739

Editorial responsibility: Garriet Smith, Aiken, South Carolina, USA
Thompson FL, Barash Y, Sawabe T, Sharon G, Swings J, Rosenberg E (2006) Thalassomonas loyana sp. nov., a causative agent of the white plague-like disease of corals on the Eilat coral reef. Int J Syst Evol Microbiol 56: 365-368

Vargas-Yanez M, Garcia M, Salat J, Garcia-Martinez M, Pascual J, Moya F (2008) Warming trends and decadal variability in the Western Mediterranean shelf. Global Planet Change 63:177-184

> Vezzulli L, Previati M, Pruzzo C, Marchese A, Bourne DG, Cerrano C (2010) Vibrio infections triggering mass mortality events in a warming Mediterranean Sea. Environ Microbiol 12:2007-2019

- Vezzulli L, Pezzati E, Huete-Stauffer C, Pruzzo C, Cerrano C (2013) 16SrDNA Pyrosequencing of the Mediterranean gorgonian Paramuricea clavata reveals a link among alterations in bacterial holobiont members, anthropogenic influence and disease outbreaks. PLoS ONE 8: e67745

> Walker DI, Ormand RFG (1982) Coral death from sewage and phosphate pollution at Aqaba, Red Sea. Mar Pollut Bull 13:21-25

Weil E (2004) Coral reef diseases in the wider Caribbean. In: Rosenberg E, Loya Y (eds) Coral health and disease. Springer, Heidelberg, p 35-68

> Weinberg S (1978) Mediterranean octocorallian communities and the abiotic environment. Mar Biol 49:41-57

> Wirgin I, Marceda L, Stabile J, Mesing C (1997) An evaluation of introgression of Atlantic coast striped bass mitochondrial DNA in a Gulf of Mexico population using formalin-preserved museum collections. Mol Ecol 6: 907-916

Woodley CM, Bruckner AW, McLenon AL, Higgins JL, Galloway SB, Nicholson JH (2008) Field manual for investigating coral disease outbreaks. NOAA Teck Memo NOS NCCOS 80 and CRCP 6. National Oceanic and Atmospheric Administration, Silver Spring, MD

> Work TM, Richardson LL, Reynolds TL, Willis BL (2008) Biomedical and veterinary science can increase our understanding of coral disease. J Exp Mar Biol Ecol 362: 63-70

Submitted: March 24, 2014; Accepted: May 13, 2014 Proofs received from author(s): August 12, 2014 